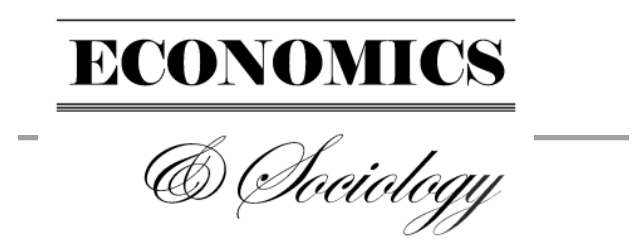

Mura, L., \& Kljucnikov, A. (2018). Small Businesses in Rural Tourism and Agrotourism: Study from Slovakia. Economics and Sociology, 11(3), 286-300. doi:10.14254/2071-789X.2018/11-3/17

\author{
Ladislav Mura, \\ Pan-European University in \\ Bratislava, \\ Bratislava, Slovakia, \\ E-mail: ladislav.mura@gmail.com
}

\begin{abstract}
Aleksandr Ključnikov, University of Entrepreneurship and Law in Prague,

Prague, Czech Republic

E-mail:kliuchnikov@gmail.com
\end{abstract}

Received: December, 2017

1st Revision: March, 2018

Accepted: June, 2018

DOI: $10.14254 / 2071-$

789X.2018/11-3/17

\section{SMALL BUSINESSES IN RURAL TOURISM AND AGRO TOURISM: STUDY FROM SLOVAKIA}

JEL Classification: L26, L83, Z32

\begin{abstract}
Microbusinesses and small enterprises are the dominant representatives of business in the rural environment, and also active players contributing to regional development. Rural areas of Slovakia are still considered to be underused. Exploiting the potential of rural regions is the key to the recovery of rural businesses. Development of rural areas depends on the economic activity taking place in different regions. One of the possibilities for regional development is to promote specific fields of tourism, e.g., rural tourism and agrotourism. This article focuses on the evaluation of entrepreneurial activities in rural tourism based on the empirical research conducted in different regions of Slovakia. The survey sample included 142 business entities. The research was conducted between 2012 and 2016. We have applied quantitative analysis based on questionnaire survey and the Friedman test. Our research shows that benefits generated by rural tourism and agrotourism provide a positive impact on the success of businesses and help in diversification of business risks.
\end{abstract}

\title{
Introduction
}

Market-oriented economy is primarily based on small and medium-sized enterprises, accounting for more than $99 \%$ of the business activity (this is the data of the EU and the Statistical Office of Slovakia). Although multinational companies play a significant role in the global economy, in regional economy small and medium-sized enterprises dominate. Small and medium-sized enterprises are also the key to recovery from economic crises. They fill gaps at the market and can be characterized by high innovation capacity (Zauskova \& Madlenak, 2012; Ivanova \& Cepel, 2018) as well as high degree of flexibility and growing employment opportunities (Svec \& Madlenak, 2017; Dobeš et al., 2017; Kljucnikov \& Popesko, 2017; Fominiene, 2016). Small and medium-sized enterprises perform many economic functions, e.g., production, employment and regional development functions (Hudakova et al. 2017) all of which have the highest importance for local, regional and national economies (Serbin \& Serbin, 2018; Tvaronavičienè \& Razminienè, 2017).

Self-employed farmers and small enterprises, primarily providing services, are the basic forms of SMEs in rural areas. As compared to large companies, small and medium-sized 
enterprises are more vulnerable and sensitive to market changes. According to (Sobeková Majková, 2011) or Glova \& Gavurova (2012) businesses in financial sector are particularly vulnerable, because they do not have enough own capital to cover their debts or pay interest on business loans. They are sensitive to exchange rate and currency risks in trading with foreign business partners. The role of the state as a specific participant at the market is to create suitable conditions for the development of small and medium-sized enterprises, provide support in the course of their development and ensure such legislative environment from which small and medium-sized enterprises can benefit (Vojtovic, 2016; Virglerová et al., 2016).

According to (Belás, Vojtovič \& Ključnikov, 2016) microenterprises struggle the most with the problems of entrepreneurship. They are most sensitive to changes in regional market conditions and are also exposed to a variety of financial risks (Ivanova \& Latyshov, 2018). Sobeková Majková (2016) also points out the impact of financial risk factor and emphasizes on the high level of vulnerability of small businesses. Štreimikiene \& Ališauskaitè-Šeškienè (2016) results show that microenterprises of the Central European countries are most vulnerable to bankruptcy. Thus, they deserve more attention from the government, scientists and business support organizations. According to Musa et al. (2016) it is also necessary to look for financial support mechanisms dedicated to supporting the creation and growth of small and medium-sized enterprises in the era of globalized economy. Rajnoha et al. (2016) emphasize that financial questions should be part of the complex financial management in order to maintain competitiveness. Such a managerial attitude is also supported by (Rogalska, 2014) and (Pellesova \& Kajzar, 2016).

Slovakia is a mountainous country; half of the country area is covered by forests and mountains. These natural conditions predetermine high natural potential for the regional development. The tourism is one of the most dynamically developing sectors with an increasing potential year by year (Yalçinkaya, Daştan \& Karabulut, 2018). This background has developed our interest to explore the current trends in rural and agrotourism management.

\section{Literature review}

Small and medium-sized enterprises have an irreplaceable role in workplace creation and regional development in Slovakia. Agriculture and rural areas are currently performing multiple tasks and functions (Chrenekova et al. 2015; Lincényi \& Fabuš, 2017; Lengyel et al. 2017; Takac et al., 2015). Experts are discussing the multi-functionality of the rural area, which is seen as an economic diversification of the countryside (Sebik et al. 2015). The rural settlements in Slovakia also differ in their potential for the development of tourism related activities. The issue of rural development is an important policy in the member states of the European Union (Lietava \& Fáziková, 2017; Pichler, 2018). This sector has a great growing potential and does contribute to the stabilization of the economic and social development. The countryside has a great potential not only in the field of agricultural production, but also in the development of tourism, entrepreneurship and the economic activity of the population. It should be based on respecting the needs of visitors and real possibilities of providing services in the rural area (Mura \& Šulterová, 2012).

The European Union is a union of regions. The development of regions is a key issue of the European Union. The agriculture is not currently as strong sector as it was in the $20^{\text {th }}$ century. Considering both the economic development and maintaining the employment in the rural areas it is important for the businesses to introduce innovations, which can help the further development of the region (Fáziková, 2011). Selected aspects of the innovation policies of businesses in rural areas were also discussed by Machová et al. (2016). The importance of the further development of Slovak regions was similarly emphasized by 
Ivanová \& Masárová (2016). The implementation of new activities is contributing not only to the acceleration of business activities, but also to the increase of the economic growth, enhancing of the social inclusion and the development of cultural and social activities. These determinants are the basis of the regional development. Businesses in cooperation with the local municipalities play an irreplaceable role in fulfilling of this demanding task. Korcsmáros (2012) states, that the importance of small and medium-sized enterprises in terms of regional development is extremely high. In her work, the author focused on the quantification of the impact of the activities of small and medium-sized enterprises on the development of Nitra region. The research confirms an existence of a significantly positive contribution to the economic and social development of the region, brought by the small and medium-sized enterprises.

Bosáková et al. (2015) also emphasize the importance of micro and small enterprises and find them useful for the development of individual regions of Slovakia. The regional development of Slovakia is mainly based on the business activities of the regional enterprises. Their activities contribute to economic development of the country. The success of business entities in the tourism industry is based on the qualified and motivated workforce, which is one of the most important factors of corporate success (Vetraková \& Kubal'a, 2016; Strielkowski, 2017; Vovk \& Vovk, 2017).

According to Habánik et al. (2016) or Gavurova et al. (2017) building of a competitive Slovak economy is also determined by the regional development policy. The regional and local authorities, regional development agencies, civil associations and other entities are the most important actors who define the regional development policy, which is a key objective of the overall economic development of the Slovak regions (Hagyari et al. 2016). The importance of an economic growth and a sustainable development in selected regions of Slovakia was also highlighted by Korauš et al. (2017). The entrepreneurial activity contributes to the socio-economic growth of the regions, making these regions stronger, more viable and competitive. The sustainable development of the region should be the main objective of the participants. Determinants of the economic growth in V4 countries is a highly discussed issue also in the Czech Republic, and especially in the Moravian regions (Kajzar \& Vaclavinkova, 2016). The support of rural and agrotourism is an integral part of the regional development (Mardani, 2016). Topcu (2016), Bohatova et al. (2016) and Radovic et al. (2017) state that rural tourism and agrotourism should be important while planning tools for the sustainable regional development and multifunctional agriculture.

Agriculture, as a former dominant economic sector in rural areas, is no longer able to absorb most of the free labour to ensure employment in the region (Olsovska \& Svec, 2017). Therefore, it is necessary to look for different new employment opportunities for the population of the rural regions. The rural tourism and agrotourism should be considered as an option. This business activity provides an active interconnection between the agrarian activities and regional traditions to utilize the natural potential effectively, and contributes to the regional development. Slovakia has similar natural conditions for the development of this type of tourism, but is not able to fully exploit this potential, which is quite evident in comparison to the other European countries. The country is lagging in terms of several indicators, including the number of nights spent on different types of accommodation, the revenues from tourism, etc.). Beside the economic benefits, rural tourism and agro-tourism bring benefits not only for the business, but also for the regional development, employment, restoration and preservation of the cultural heritage (Streimikiene \& Bilan, 2015).

Jarábková (2010) and Pietrzak et al. (2017) point out the similar findings in their papers. According to Jarábková the rural area is an extensive area consisting of natural, human and economic potential which is used inadequately and unevenly. The development of the tourism in the regions that have the right preconditions for this type of economic activity 
is of the options, that have an impact, recognizable in the different areas of rural development e.g. in economic, social, cultural and environmental dimensions.

According to Gúčik (2011) and Kunáková et al. (2016) rural tourism is a form of tourism including the set of activities aimed at meeting the needs of those interested in the rural environment. It involves activities related to the return to nature with a possibility of accommodation offered by the local families, rural houses and various types of rural accommodation, where the offer also includes the possibility for self-catering and joining various activities closely related to the region. Agro-tourism as a part of the rural tourism is meeting the needs of those related to agrobusinesses. The tourists would like to be actively engaged in activities offered by the farms; they also want to have a contact with the owner of the facility and get information about the operation of the farm and activities nearby.

Nowadays, the urban population is looking for a relaxing holiday in the countryside. The businesses involved in rural tourism activities should respond more efficiently on this demand to ensure a sufficient number of clients. The rural tourism provides an appropriate environment for the regeneration; family activities can strengthen the health of an individual. Rural tourism is often associated with the agrotourism. This form of tourism is related to finding of the accommodation on the farms, where recreational stay is combined with some work in the orchard, the animal husbandry or the recognition of a folk culture (Jureniene \& Stonyte, 2016). The rural tourism and agrotourism provide the accommodation and further services on the farms or other recreational facilities (chalets, cottages, log cabins, owners of smaller accommodation facilities, boarding houses). Agricultural businesses provide accommodation related to their business activities (tourist hostels, chalets).

In the developed European countries rural tourism and agrotourism are developing at a considerable pace. Their prospective future development is also anticipated in Slovakia. This country has the specific conditions and a sufficient number of qualified workforces. According to Mura \& Šulterová (2012), rural tourism and agrotourism provide accommodation and additional services in different recreational facilities (chalets, cottages, $\log$ cabins); smaller accommodation facilities (hotels, boarding houses). The agricultural businesses provide the accommodation related to their business activity (hotels, boarding houses, tourist hostels, cottages). The rural tourism and agrotourism offer an alternative type of holiday for those living a hectic lifestyle. It is about staying in the natural environment and the possibility to develop close contact with the local inhabitants. Those, interested in this type of activity, will explore new and unknown destinations. By generating the demand for this type of tourism the crowdedness of mass tourist resorts will decrease. The rural tourism can also contribute to protection of the environment.

As Nunvářová (2007) emphasizes, the development of the rural tourism is one of the possible options to support the rural development. It is an activity that helps to utilize the rural facilities and to preserve traditions of rural life, as well as to increase the employment in rural regions. There is an increasing number of those forms of tourism where the natural environment, cultural and historical heritage are also considered.

Tourism is an important economic sector (Bačík et al. 2016). Based on this fact, Matisková (2011) emphasizes a new strategy of Slovakia, which is harmonized with the EU strategy concerning tourism, rural tourism and agro-tourism. There are two key areas: sustainable development of regions and tourism industry in the context of ensuring employment facilities in the rural areas. It provides a chance for the development of the regional economy, employment facilities and preservation of traditions in the rural regions.

Mikalauskiene et al. (2016) emphasized, that the globalization, internationalization and integration processes have not missed every economic sector, including the tourism industry (Vincúrová, 2017), and especially in the EU (including new member states like Slovakia) the business environment has been improving and creates new possibilities for 
various industries (Głodowska, 2017). They have made many positive contributions to the tourism, including an increased mobility of tourists, the removal of barriers to travel to different destinations, free access to destinations and the increased revenues in foreign currency. Stronger development of tourism has helped to bring different cultures closer (Saulius et al. 2016), to recognize the traditions and customs of the different rural areas. Slovak business environment, including the sub-sectors of the rural tourism activity, might react more efficiently on these tendencies.

Based on the opinion of professionals and research results presented in the theoretical part of this contribution, it is clear that tourism and rural tourism play the key role in the economic and sustainable development of region. The activity of small enterprises is a major source of the economic activity in the rural areas, ensuring increasing employment, income, flow of capital and regional development. Although Slovakia is a rural and mountainous country, there is still a considerable scope for the further development of business activities in the tourism sector.

\section{Methodological approach}

The business entities operating in rural tourism and agrotourism in Slovakia are the subject of this research. The research results are based on the repeated empirical researches conducted between the years 2012 and 2016. A total number of 200 companies were addressed in the particular sector of the national economy. Because of the absence of a common register and the mandatory central registration of these business entities, those businesses were targeted in the stratified sampling, where the rural tourism and agro-tourism were indicated as a subject of their business activity. The willingness to participate in the research was demonstrated by 166 business entities. The research sample is made up of 142 companies, representing different regions of Slovakia. The correction of the number of companies involved in the research was made due to submitting of the incomplete answers for the questionnaire survey resp. not providing the necessary data.

The studied problem required not only the data based on the empirical research, but also the secondary data, that were collected and generated out of the relevant scientific publications, mainly published in the scientific journals and scientific conferences' proceedings. The primary data were collected via the questionnaire research and further data were gained during the research conducted earlier.

The main objective of this article is to highlight the current situation of small and medium-sized enterprises in tourism industry and its sub-sector of rural tourism and agrotourism. This research is focused on the factors that affect the business activity of the selected enterprises. The methodological approach applied is based on the objective set to solve the research issue related to rural tourism and agro-tourism. The chosen research methodology is subordinated to the set objective. Considering the nature of the research, regression analysis and the Friedman test were applied. Regression analysis is a kind of statistical analysis that is used to predict the results. It estimates the existence of the relationship between the variables and enables the estimation of the value of one variable using other known values of the variables. We can use it to predict the future values by extending the trend line in the graph for the current data area. The regression line is defined as the following:

$$
\mathrm{Y}^{\prime}=\beta_{0}+\beta_{1} \mathrm{X}
$$

The Friedman test is used to verify the relation between the categorical and ordinal variables (factor). The samples typically consist of the repeated measurements of the same 
objects, measured at the different time points, and possibly under the different conditions. The advantage of the dependent selections makes it easier to find the significant differences compared to the independent ones. Small, but consistent differences can be identified despite the large differences between the subjects. The Friedman test is a non-parametric test of twofactor scattering analysis. The input data is arranged in a matrix, where the rows are indicated with „m“ and columns with „n“. The testing statistics of the Friedman test is:

$$
F=\frac{12 \cdot m}{n \cdot(n+1)} \cdot \sum_{j=1}^{n}\left[\sum_{j=1}^{m} T_{i j}-\frac{n+1}{2}\right]^{2}
$$

As a part of this research we have determined and subsequently tested the validity of the working hypotheses. The hypotheses testing was conducted at a significance level of $\alpha=0,05$. The hypothesis Ho is rejected if $\mathrm{F}>\mathrm{CV}$ (critical value). The processing of the underlying data was carried out with the help of MS Office software and the statistical processing was conducted with the help of the statistical software SAS.

We have tested the following hypotheses:

$\mathrm{H}_{0}$ : there is no statistically significant difference between the motivational tools applied in relation to employees.

$\mathrm{H}_{1}$ : there is a statistically significant difference between the motivational tools applied in relation to employees.

\section{Results and Discussion}

The following part of the article introduces the research findings. A rural countryside is dominating in most of the regions of Slovakia, where each region has its own characteristic features and specificities, as well as has something to offer for visitors. The main types of tourism in various regions are documented below. We have 21 tourist regions in Slovakia. According to the map, the rural tourism is established in 14 regions of the country, therefore is considered to be a major form of tourism. Long-term potential for rural tourism can be found in the following regions: Orava, Liptov, Upper Hron River Region, Northern Váh Region. Good potential for rural tourism is provided by regions of Middle Váh Region, Danube River Region, Turiec, Ipel', Gemer, Hron River Region, Tatras and Spiš. For the other areas the long-term potential for rural tourism has been characterized as average or baseline.

Rural tourism is considered to be the main form of tourism in two thirds of the tourism regions. The municipalities and regions should realize activities for the further development, do not focus only on the marketing of the regions and villages, but also on the improvement of the infrastructure and the decrease of unemployment by creating workplaces.

Before presenting the results of our empirical research, we will introduce the basic characteristics of the research sample. 142 small and medium-sized businesses from various regions of Slovakia were involved in the survey. These businesses are active in the rural and agrotourism. 90 of the enterprises involved in the survey were natural persons (microenterprises) and 52 of them were legal entities. Graph \#2 shows the distribution of enterprises in individual self-governing regions involved in our research. 


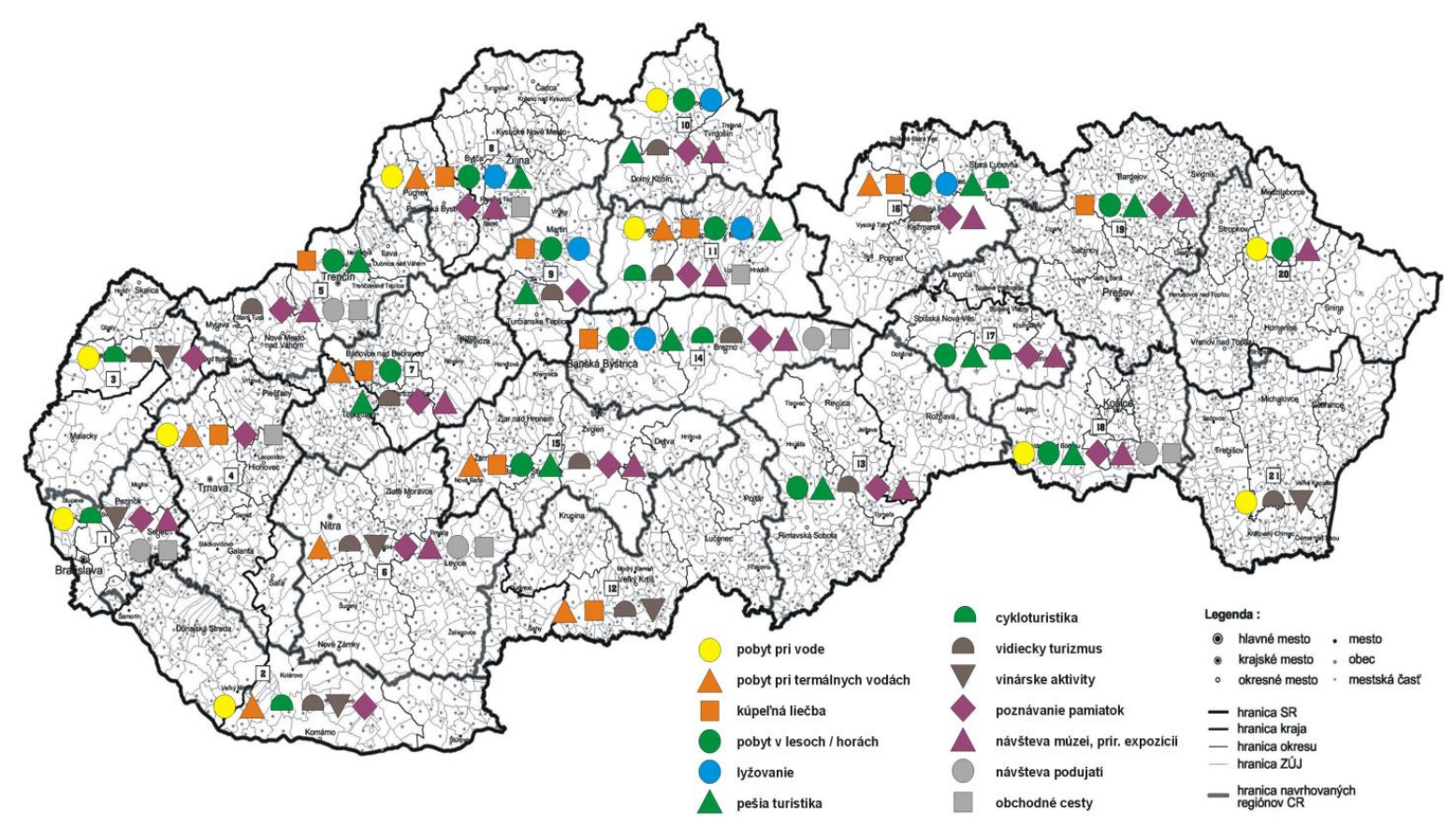

Graph 1. The main types of tourism in different regions

Source: Ministry of Economy of the SR

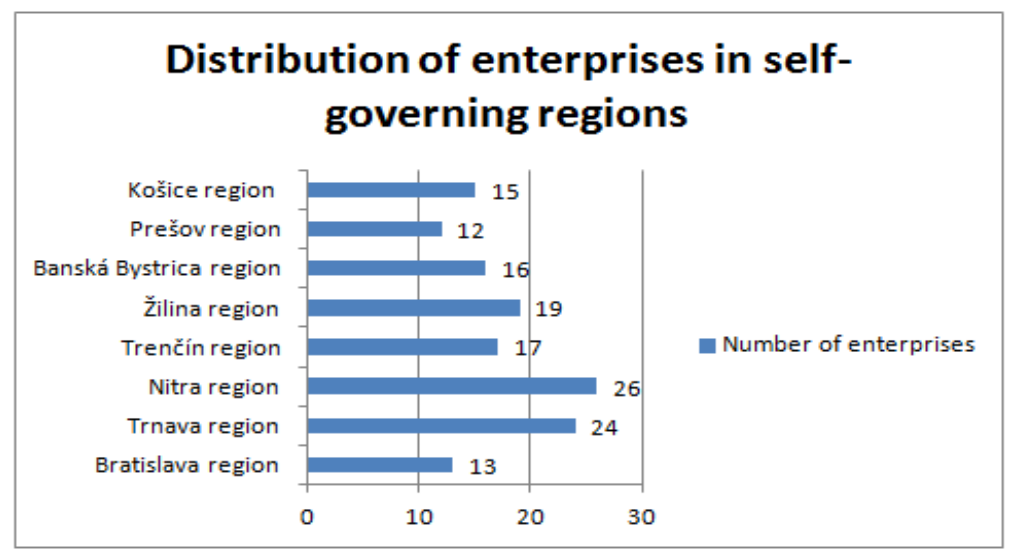

Graph 2. Distribution of enterprises in self-governing regions in the research Source: primary research, own processing

The graph \#2 illustrates the number of business entities involved in our primary research. Most of the enterprises are found in Nitra and Trnava region, which corresponds to the natural-geographical conditions and agricultural focus of these rural areas. The conditions for the rural development are also favourable in the northern part of Žilina region (Kysuce, Orava) and Trenčín region, mainly dominated by Kopanice, which is known for the rural tourism. This is followed by the regions of Banská Bystrica and Košice, where the "magnet" for the development of the rural tourism is preserved in folklore, folk crafts, historical monuments and agro-tourism in the southern regions. Bratislava and Prešov regions reached the smallest ratio in the survey.

We were interested in the period of establishment of tourist facilities involved in our research. The findings are demonstrated in the Graph \#3. Most of the tourist facilities were established in time interval of 1990-1995 and 1996-2000. This boom in establishing tourist 
facilities in the rural and agro-tourism was linked to the transformation of the agricultural business activities. The businesses were looking for the new revenue sources beside their traditional agricultural activities. The boom of the rural tourism in the $1990 \mathrm{~s}$ of the $20^{\text {th }}$ century was related to the implementation of the Village Rehabilitation Program and other support mechanisms aimed at stabilizing and developing the rural settlements. Less than fifth of the tourist facilities participating in our research were established after the year of 2000. It was followed by a gradual decline in the establishment of tourist facilities in this sector of tourism.

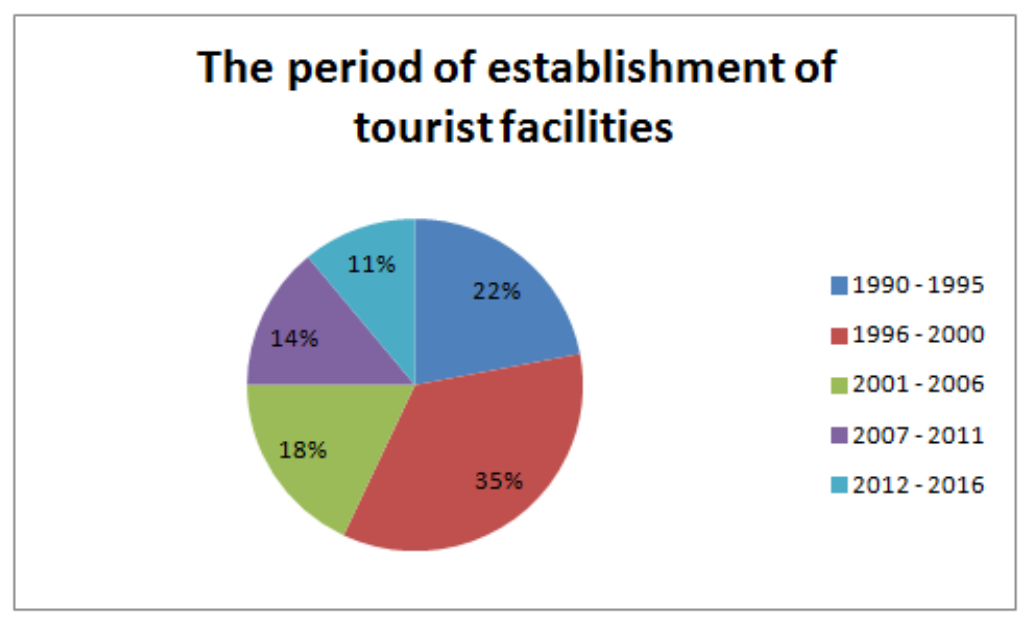

Graph 3. The period of establishment of tourist facilities

Source: primary research, own processing

Following this question we were interested in the character of the establishment of these tourist facilities in the 1990s of the $20^{\text {th }}$ century. The findings are shown in Graph 4.

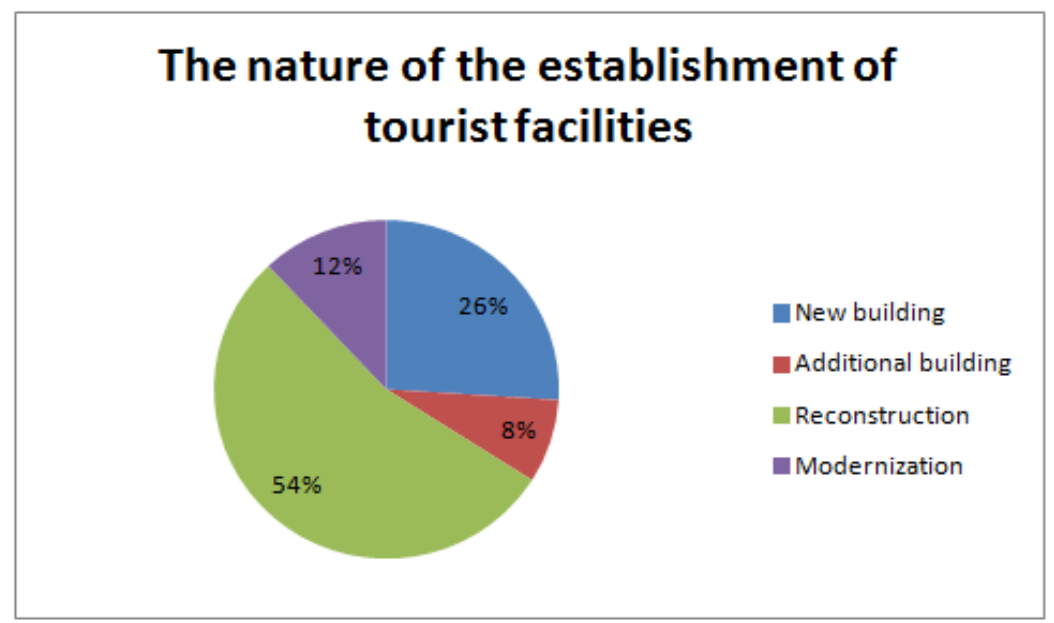

Graph 4. The nature of the establishment of tourist facilities

Source: primary research, own processing

The graph \#4 indicates that half of the tourist facilities resulted as a reconstruction of existing buildings owned by businesses. The majority of them were unused administrative buildings, which have become the accommodation facilities after the reconstruction. The effort of management to increase the efficiency of utilizing of the existing business assets is highly appreciated. The support programme schemes were also used to realize these activities. A bit more than a quarter of the companies stated that their tourist facilities were built as a 
new building. The modernization of the existing accommodation facilities was realized by $12 \%$ of the enterprises. Only $8 \%$ of the enterprises built an accommodation facility as an extension of the existing building.

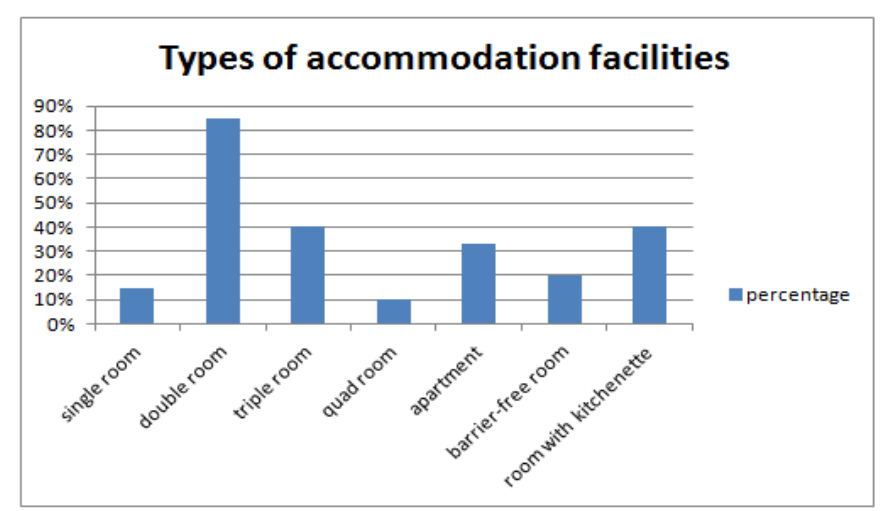

Graph 5. Types of accommodation facilities

Source: primary research, own processing

We also investigated what type of accommodation is provided by businesses involved in rural and agro-tourism. The results are shown in the Graph \#5. Most of the accommodation facilities in the rural tourism can be characterized as the double rooms, the triple rooms and the apartments. More than a third of the accommodation has a separate kitchen. Less than a fifth of facilities provide a single room. A positive finding is that one fifth of these facilities provide a barrier-free room for the guests.

Each business, including businesses providing services in the rural and agrotourism employ the professional staff, which can be considered as the basic pillar of a successful entrepreneurship. As a part of our analysis we also focused on how the number of employees developed in businesses are involved in our research. The following parameters were considered while examining the employees: the total number of the employees with a permanent contract, the number of the employees in production and the number of the employees in the rural tourism. The regression analysis demonstrates the trend of development (Graph \#6).

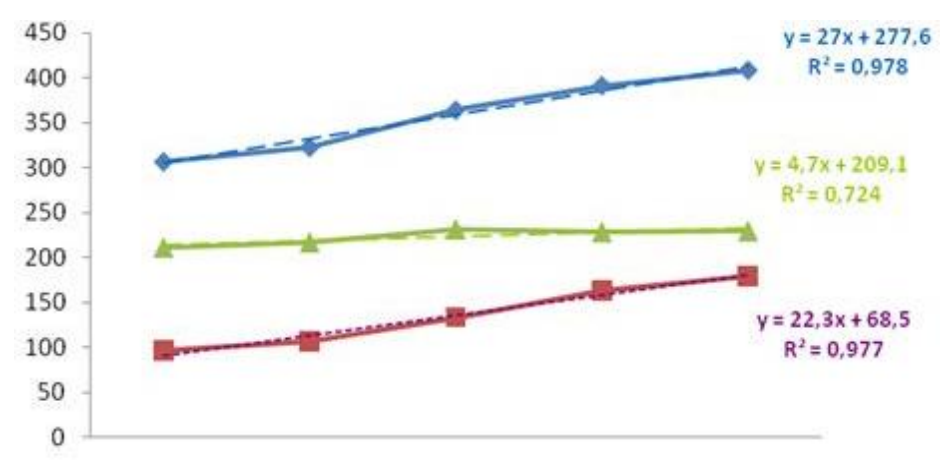

Graph 6. Quantitative analysis - the number of the employees

Source: primary research, own processing

Notice: the blue line indicates the total number of employees

the green line indicates the number of employees in the production

the red line indicates the number of employees in rural tourism (linear regression) 
The graph \#6 shows the data about the number of the employees in the different units, the consequent analysis of the employees in the production and the employees working in rural tourism. The economic crisis has not had a strong negative impact on the production sector, because the agricultural products are the basis of nutrition. Similarly, the economic crisis had no negative impact on the rural tourism. This is the least costly form of tourism that remained affordable for people even in an economically unfavourable period. The rural tourism is mainly popular among the urban inhabitants and the families with children.

An increasing qualification, professional knowledge or skills are essential in the human resources management. This is the main reason why we conducted a regressive analysis, where we were interested in the basic categories of employees, that were categorized according to their level of education, including higher education, secondary vocational education, secondary education and elementary education. Graph \#7 illustrates the results of the analysis.

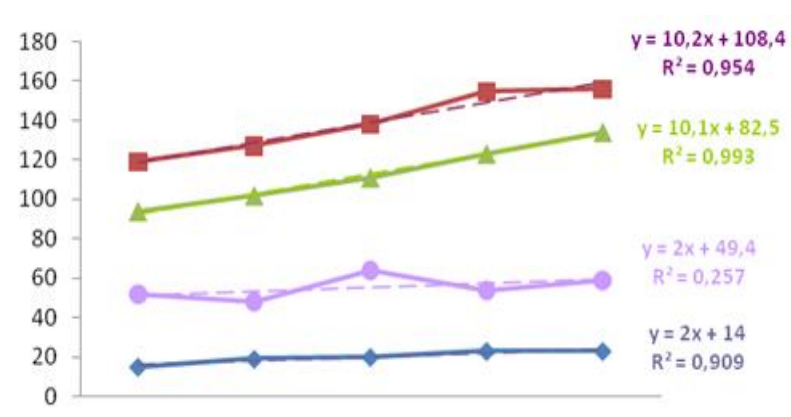

Graph 7. Quantitative analysis - employee qualification

Source: primary research, own processing

Notice: the blue line indicates the employees with university degree

the purple line indicates the employees with primary education

the green line indicates the employees with secondary education

the red line indicates the employees with completed secondary vocational education

The graph \#7 states that the number of the employees in the agrotouristic facilities according to the level of education shows a linear development in case of the employees with the university degree, secondary school and secondary vocational school degree, where the correlation coefficient is higher than $0,5 . \mathrm{R}^{2}$ hase a value of 0,257 in case of the employees with a primary level of education, which is not considered to be a significant value.

It is very important for the managers to be aware of an adequate motivation of their employees while working with people. The qualified and properly motivated staff is the basic pillar of the entrepreneurship. We were interested in the motivation tools the managers apply. The financial incentives (over 80\%) are still the most popular tool of motivation, followed by the quality of the working environment (two-thirds). Half of the respondents find the personality of the manager to be important. A self-realization is important for $34 \%$ of the respondents. The least important tools of motivation were the social benefits and the geographical distance from the workplace. We applied the Friedman test to verify, whether the identified differences regarding the motivation tools and employee motivation are only random or are statistically significant. We have tested the following hypotheses:

$\mathrm{H}_{0}$ : there is no statistically significant difference between the motivational tools applied in relation to employees. 
$\mathrm{H}_{1}$ : there is a statistically significant difference between the motivational tools applied in relation to employees.

According to the results of the Friedman test, $\mathrm{H}_{0}$ hypothesis can be rejected, because the value $F=161,1$ and the critical value of $C V=15,51$. It means that $F>C V$. We accept the hypothesis $\mathrm{H}_{1}$, which shows a significant difference between the motivational tools in relation to the employees.

In our analysis we were also interested in the entrepreneurial success of businesses operating in the rural and agrotourism. For all companies involved in our research, the tourism is not the only but one of the fields of their business activity.

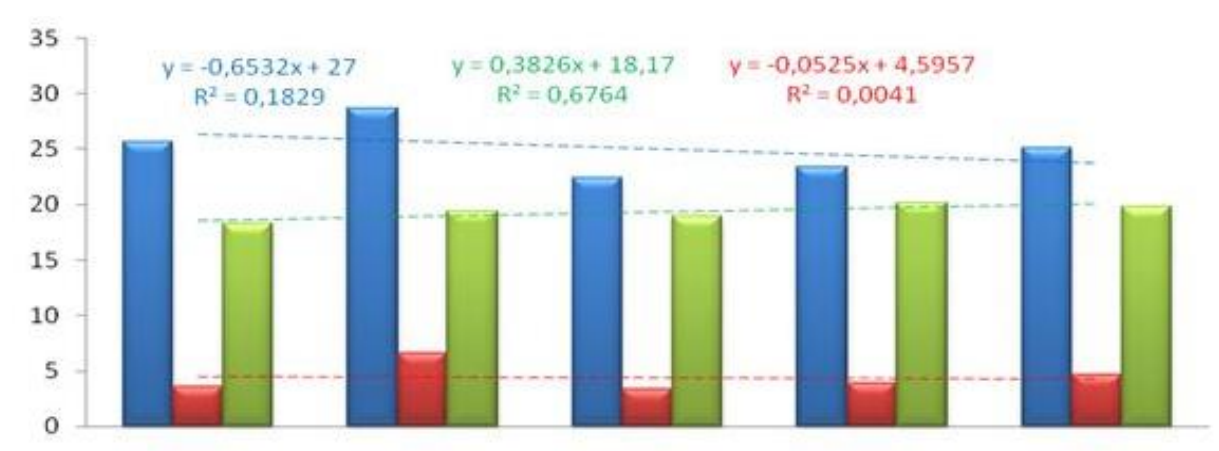

Graph 8. Quantitative analysis of the entrepreneurial success between 2012 and 2016

Source: primary research, own processing

Notice: the blue colour indicates the annual economic result of the business

the red colour indicates the annual economic results achieved by the companies in the rural and agro-tourism

the green colour indicates the economic results achieved in production

The graph \#8 shows that entrepreneurship in rural and agrotourism positively contributes to the overall success of businesses operating in this sub-sector of tourism. The revenue generated from this business activity is only supplementary and not the main source of income. More space should be created to increase the success of these businesses with more effective support of marketing activity.

\section{Conclusion}

The private business entities, a significant position among which is held by the small enterprises, are the catalysts of the local and national economic development. Following the disappearance of the larger employers in the rural area, small and medium-sized enterprises gained higher importance and became the key players of the regions.

More than two-third of Slovakia is a countryside. Approximately half of the inhabitants live in these areas. The rural tourism and agrotourism will not solve all the economic, social and other problems of the Slovak countryside, but yet they are the good tools for the diversification of the economic and social activities, as well as for the improvement of the services that are currently missing in the less developed areas of the country. It requires more support, cooperation and better administrative and legislative background, which have been highlighted by experts, entrepreneurs and mayors for a long time.

This is the reason why it is necessary to pay an increased attention to this segment of enterprises, not only in practice but also in the research activities. It is necessary to support the development of this form of entrepreneurship in the countryside. Based on the earlier 
research results and the results of the current research we can identify some problems that need to be addressed in the future and that can be perceived as an opportunity for the development. The previous research of the authors had shown the similar findings. According to Mura and Šulterová (2012), the development of the rural tourism has a great potential, because more and more people have developed an interest in destinations far from the noise, smog and urban areas. The hospitality and tourism can contribute to the development in the different regions of Slovakia.

A research was conducted on a sample of 142 enterprises in the field of rural tourism in the different regions of Slovakia in the time interval between the years 2012 and 2016. We applied a quantitative analysis based on the questionnaire survey and the Friedman test. Our research show that benefits generated by the rural tourism and the agrotourism provide a positive impact on the success of business and help in the diversification of business risk.

The most important research outputs are the following. The economic crisis did not have any negative impact on the rural tourism. This is the least costly form of tourism that remained affordable for people even in an economically unfavourable period. The rural tourism is popular among the urban inhabitants and families with children. The number of the employees in agrotouristic facilities according to achieved level of qualification shows a linear development in case of the employees with the university degree, secondary school and secondary vocational school degree, where the correlation coefficient is higher than $0,5 . \mathrm{R}^{2}$ has a value of 0,257 in case of the employees with the primary level of education, which is not considered to be a significant value. According to the results of the Friedman test, $\mathrm{H}_{0}$ hypothesis can be rejected, because the value $F=161,1$ and the critical value of $C V=15,51$. It means that $\mathrm{F}>\mathrm{CV}$. We accept the hypothesis $\mathrm{H}_{1}$, showing a significant difference between the motivational tools in relation to the employees.

The rural tourism and agrotourism can be perceived as the most promising business activities, that can become a stabilizing factor in the economic and social development of the rural settlements, as they are an essential part of the regional development. The practice shows that despite of the rural and mountainous landscape of Slovakia, tourism and rural tourism in the different regions are not as developed as it is be desirable. During our research we have identified these fields of improvements:

- the price should reflect the quality of the service,

- supplementary services should be offered,

- weak marketing communication,

- weak cooperation with the other players of the tourism industry (travel agencies, regional tourism organizations, local authorities),

- weak networking with entrepreneurs,

- friendliness and motivation of the employees,

- creativity and initiative to solve the problems.

\section{Acknowledgement}

This paper was supported by the Grants of GAAA 19/2018 and KEGA 001UCM-4/2016.

\section{References}

Bačík, R., Mudrik, M., Štefko, R., \& Kot, S. (2016) Analysis of tourism travel trends after 2014. Journal of Environmental Management and Tourism, 7(1), 88-93.

Belás, J., \& Sopková, G. (2016). A model of entrepreneurial orientation. Transformation in Business \& Economics, 15 (2B), 630-644. 
Belás, J., Vojtovič, S., \& Ključnikov, A., (2016). Microenterprises and Significant Risk Factors in Loan Process. Economics and Sociology, 9 (1), 43-59.

Bohatova, Z., Schwarcz, P., Schwarczova, L., Bandlerova, A., \& Tl'cik, V. (2016). Multifunctionality - interactions and implications: the case of the Podkylava village (Western Slovakia). European Countryside, 8 (2), 147-159, SI.

Bosakova, L., Kubak, M., Andrejkovic, M., \& Hajduova, Z. (2015). Doing business abroad: utility function model for country selection in preliminary screening phase. Central European Journal of Operations Research, 23 (1), 53-68.

Dobeš, K., Kot, S., Kramoliš, J., \& Sopková, G. (2017). The Perception of Governmental Support in The Context of Competitiveness of SMEs in the Czech Republic. Journal of Competitiveness, Vol. 9, Issue 3, pp. 34-50.

European Union. Entrepreneurship and Small and medium-sized enterprises. https://ec.europa.eu/growth/smes_sk.

Fáziková, M. (2011). Innovation precesses in agriculture in the rural region. 14th International colloquium on regional sciences, 217-224.

Fominiene, V. B. (2016). The Importance of Tourism Websites to Tourism Services And Assurance Of Their Competitiveness. Montenegrin Journal of Economics, 12(4), 41-51.

Gavurova, B., Soltes, M., \& Kovac, V. (2017). Application of cluster analysis in process of competitiveness modelling of Slovak republic regions. Transformations in Business \& Economics, 16 (3), 129-147.

Glova, J., Gavurova, B. (2012). Perspectives in assessment of intellectual capital. Hradecke ekonomicke dny 2012, PT I , 73-78.

Głodowska, A. (2017). Business Environment and Economic Growth in the European Union Countries: What Can Be Explained for the Convergence?. Entrepreneurial Business and Economics Review, 5(4), 189-204. doi: https://doi.org/10.15678/EBER.2017.050409

Gúčik, M. (2011). Cestovný ruch: politika a ekonómia, 188.

Habánik, J., Kordoš, M., \& Hošták, P. (2016). Competitiveness of Slovak economy and regional development policies. Journal of International Studies, 9 (1), 144-155.

Hagyari, P., Bačík, R., \& Fedorko, R. (2016). Analysis of the key factors of reputation management in conditions of city marketing. Polish Journal of Management Studies, 13(1), 69-80.

Hudáková, J., Fila, M., \& Maroš, M. (2017). Innovation potential of the regions in the Slovak republic. Acta Oeconomica Universitatis Selye, 6 (2), 81-88.

Chrenekova, M., Melichova, K., \& Majstrikova, L'. (2015). Development activities in districts of Zilina region in frame of cohesion policy. 18th International Colloquium on Regional Sciences, 286-292.

Jarábková, J. (2010). The rural areas - the unutilized potential in light of tourism. Agricultural Economics - Czech, 56 (11), 532-539.

Ivanová, E., \& Masárová, J. (2016). Assessment of innovation performance of Slovak regions. Journal of International Studies, 9 (2), 207-218.

Ivanova, E., \& Cepel, M. (2018). The impact of innovation performance on the competitiveness of the Visegrad 4 countries. Journal of Competitiveness, 10 (1), 54-72.

Ivanova, S.; \& Latyshov, A. (2018). Sustainable entrepreneurship: agrarian policy in South Korea. Entrepreneurship and Sustainability Issues 5(4), 748-760.

Kajzar, P., \& Vaclavinkova, K. (2016). Prerequisites adventure tourism in the Moravian region with a focus on rural and industrial tourism. 19th International Colloquium on Regional Sciences, 1008-1015.

Ključnikov, A., \& Popesko, B. (2017). Export and its Financing in The SME Segment. Case Study From Slovakia. Journal of Competitiveness, 9 (1), 20-35. 
Koraus, A., Simionescu, M., Bilan, Y., \& Schönfeld, J. (2017). The impact of monetary variables on the economic growth and sustainable development: Case of selected countries. Journal of Security and Sustainability Issues, 6 (3), 383-390.

Korcsmáros, E.D. (2012). The importance os SMEs in terms of development of the Nitra Region. Aktualne problemy podnikovej sfery, 59-62.

Kunáková, L., Štefko, R., \& Bačík, R. (2016). Evaluation of the landscape potential for recreation and tourism on the example of microregion Mincol (Slovakia). e-Review of Tourism Research, 13(1-2), 335-354.

Lengyel, P., Oláh., J., Pancsira, J., Fuzesi, I., \& Popp, J. (2017). Advantages of using lms in training for agricultural advisors. Acta Oeconomica Universitatis Selye, 6 (2), 109-118.

Lietava, M., \& Fáziková, M. (2017). Selection of EU finaced projects and the territorial cohesion. Acta Oeconomica Universitatis Selye, 6 (1), 71-82.

Lincényi, M., \& Fabuš, M. (2017). Economic trends of business actors on daily newspaper market: case of the Slovak Republic, Entrepreneurship and Sustainability Issues, 5(1), 91-104.

Machová, R., Huszárik, E.S., \& Šimonová, M. (2016). Selected aspects of innovation policy for small and medium sized enterprises. Journal of International Studies, 9 (2), 219232.

Matisková, D. (2011). Ekonomické aspekty Prešovského regiónu v súvislosti s cestovným ruchom. Regionální rozvoj a cestovný ruch, 158-170.

Mikalauskiene, A., Štreimikiene, D., \& Mulagalejeva, K. (2016). Assess the impact of globalisation processes by indices. Economics and Sociology, 9 (4), 82-100.

Ministerstvo hospodárstva SR. Stratégia rozvoja cestovného ruchu do roku 2020. Dostupné na: http://www.telecom.gov.sk/index/index.php?ids=102068.

Mura, L., \& Šulterová, S. (2012). Manažment rozvoja vidieckeho turizmu a agroturizmu v regiónoch Slovenska a ich perspektívy. Bučovice: Martin Stř́ž, 168.

Musa, H., Strokova, Z., \& Musova, Z. (2016). Financing of slovak small and medium sized enterprises in globalising environment. Globalization and its socio-economic consequences, 16th International scientific conference proceedings, PTS I-V, 14581465.

Nuňvářová, S. (2007). Rozvoj venkova, 211.

Olsovska, A., \& Svec, M. (2017). The Admissibility of Arbitration Proceedings in Labour Law Disputes in Slovak Republic. E-Journal of international and comparative labour studies, 6 (3), 112-123.

Pichler, J. (2018). In Quest of SME-Conducive Policy Formulation. Entrepreneurial Business and Economics Review, 6(1), 105-113. doi: https://doi.org/10.15678/EBER.2018.060106.

Pellesova, P., Kajzar, P. (2016). Selected theoretical knowledge of revenue management. Sbornik mezinarodni vedecke konference: hotelnictvi, turismus a vzdelavani, 160-167.

Pietrzak, M. B.; Balcerzak, A. P.; Gajdos, A.; Arendt, L. 2017. Entrepreneurial environment at regional level: the case of Polish path towards sustainable socio-economic development, Entrepreneurship and Sustainability Issues, 5(2), 190-203.

Radovic, D., Strielkowski, W., Wang, J., Cepel, M., \& Rausser, G. (2017). Economic Analysis of Sustainable Tourism: a Case Study of Nottingham. Transformations in Business \& Economics, 16(2B), 703-714.

Rajnoha, R., Lesnikova, P., \& Koraus, A. (2016). From financial measures to strategic performance measurement system and corporate sustainability: empirical evidence from Slovakia. Economics and Sociology, 9 (4), 134-152.

Rogalska, E. (2014). Enterprise the view of managerial theories of the firm. Oeconomia Copernicana, 5 (1), 153-174. 
Saulius, T., Valanciene, D., Skurvydas, A. (2016). Explanatory Value of the Culture Concept in the Contexts of International Business Communication. Transformations in Business \& Economics, 15 (2B) (38B), 766-783.

Serbin, S., \& Serbin, A. (2018). Bromic Heating Co business exposure project to the Chile market. Economics, Management and Sustainability, 3(1), 79-93. doi:10.14254/jems.2018.3-1.8.

Sobekova Majkova, M. (2011). The analysis of barriers and factors of small and medium-size enterprises financing in the Slovak Republic. Ekonomicky casopis, 59 (10), 1033-1049.

Sobekova Majkova, M. (2016). The influence of the selected factors on financial risk perception in Slovak SMEs. Actual Problems of Economics, 184 (10), 121-130.

Štreimikiene, D., Ališauskaitè-Šeškienè, I. (2016). Comparative assessment of external costs and pollution taxes in Baltic states, Czech Republic and Slovakia. E \& M: Ekonomie a Management, 19 (4), 4-18.

Streimikiene, D., \& Bilan, Y. (2015). Review of rural tourism development theories. Transformations in Business \& Economics, 14(2), 21-34.

Strielkowski, W. (2017). Promoting Tourism Destination through Film-Induced Tourism: The Case of Japan. Trziste, 29(2), 193-203.

Svec, M., Madlenak, A. (2017). Legal frameworks for the phygital concept. European Journal of Science and Theology, 13(6), 209-217.

Takac, I., Schwarcz, P., Lazikova, J., Bandlerova, A., \& Feher, A. (2015). Associating farmers in the producers' organisation for sustainable development of agriculture in Slovakia. International Journal of Agricultural Resources Governance and Ecology, 11 (2), SI, 105-122.

Topcu, E. D. (2016). Agro-tourism: A rural planning instrument for sustainability of agricultural lands. Journal of environmental protection and ecology, 17(2), 813-821.

Tvaronavičienè, M., \& Razminienè, K. (2017). Towards Competitive Regional Development Trough Clusters. Journal of Competitiveness, 9(4), 133-147.

Vetrakova, M., \& Kubal'a, J. (2016). Reasons for employee turnover in hotels in Slovakia. 19th International colloquium on regional sciences, 1102-1108.

Vincurova, Z. (2017). Globalization and its impact on the business sector in the Slovak Republic. Managerial trends in the development of enterprises in globalization era, 286-292.

Virglerová, Z., Dobeš, K, \& Vojtovič, S. (2016). The Perception of the State's Influence on its Business Environment in the Small and Medium Size Enterprise segment in the Czech Republic. Administratie si Management Public, 26, 78-96.

Vojtovič, S. (2016). The Impact of The Structural Funds on Competitiveness of Small and Medium-Sized Enterprises. Journal of Competitiveness, 8 (4), 30-45.

Vovk, I., \& Vovk, Y. (2017). Development of family leisure activities in the hotel and restaurant businesses: Psychological and pedagogical aspects of animation activity. Economics, Management and Sustainability, 2(1), 67-75. doi:10.14254/jems.2017.2-1.6

Zauskova, A., \& Madlenak, A. (2012). The application of the open innovation concept in the furniture industry. Wood and furniture industry in times of change - new trends and challenges, 133-139.

Yalçinkaya, Ö., Daştan, M., \& Karabulut, K. (2018). The Effects of International Tourism Receipts on Economic Growth: Evidence from the First 20 Highest Income Earning Countries from Tourism in the World (1996-2016). Montenegrin Journal of Economics, 14(3), 055-071. 